\title{
0 ato fotográfico e seu jogo poético: um percurso sobre expressões contemporâneas da fotografia a partir das relações de jogo em sua produção de sentido
}

\author{
Autor: Karina Rampazzo \\ Orientador: Alberto Carlos Augusto Klein
}

Resumo: Este trabalho tem como objetivo principal explorar as possíveis relações entre a fotografia e o jogo poético no viés da concepção criativa. Inicialmente, alguns textos da história da fotografia colaboram sobre as expressões do pensamento fotográfico atual. Os conceitos de Flusser acerca do aparelho e o branqueamento da caixa preta delimitam toda a pesquisa. As características de jogo na concepção de Caillois reforçam o entrelace dentro da discussão da fotografia enquanto ação. No campo da comunicação poética, autores como Jakobson e Pignatari, colaboram nas definições de linguagem e suas manifestações não-verbais. Assim, a pesquisa apresenta uma análise de parte da obra de quatro artistas, Carlos Fadon Vicente, Evgen Bavcar, Cindy Sherman e Abelardo Morell, tomando como base epistemológica a categorização dos jogos segundo Caillois.

Palavras-chave: Fotografia. Poética. Arte e fotografia. Comunicação visual. 


\title{
The photographic act and its poetical game: a trajectory about contemporary manifestations of photography from the relations of game in its production of meaning
}

\begin{abstract}
The main target of this work is to explore the possible relations between photography and the poetical game by bias of creative conception. At first, some texts of photography history collaborate with the manifestation of the present photographic thought. Flusser's concepts about the gadget and the whitening of the black box limit the whole research. The game's properties by Caillois increase the link in debate about photography as action. In the Field of poetical communication, authors like Jakobson and Pignatari contribute on the definitions of language and its non-verbal manifestations. Therefore, the research presents an analysis of part of the work produced by Carlos Fadon Vicente, Evgen Bavcar, Cindy Sherman and Abelardo Morell, using as epistemological basis the games categorization by Caillois.
\end{abstract}

Keywords: Photography. Poetics. Photography and art. Visual communication.

Dissertação completa disponível em: http://www.bibliotecadigital.uel.br/ document/?view $=$ vtls000191311 